\title{
Religion, Place and Modernity
}

\author{
Spatial Articulations in Southeast Asia and East Asia
}

Volume Editors: Michael Dickhardt and Andrea Lauser

Using the potential of place as an approach and of places as ethnographic contexts, the authors in this volume investigate the multiple entanglements of â $€^{\sim}$ religionâ $€^{\mathrm{m} \text { ' }}$ and $\hat{a} €^{\sim}$ modernityâ $€^{\text {mi }}$ in contemporary settings. The guiding questions of such an approach are: How are modernity and religion spatially articulated in and through places? How do these articulations help us to understand the ways in which religion becomes socially and culturally significant in modern contexts? And how do they reveal the ways in which modernity unfolds within religion? Thus, places are not only understood as neutral locations or extensions, but as spatial modes to mediate properties, contents and processes of religion and modernity. Based on ethnographic and historical research in Southeast and East Asia and featuring reflections on the concepts of religion and modernity respectively, the authors offer a deeper understanding of the articulation of a religious modernity in these regions and beyond. Contributors are: Nikolas BROYÂ, CHAN Yuk Wah, Michael DICKHARDT, Volker GOTTOWIK, Patrice LADWIG, Andrea LAUSER, Jovan MAUD, YEOH SengGuan, Clemens SIX, Paul SORRENTINO, Alexander SOUCY, Sing SUWANNAKIJ.

Readership

The book is targeted at all disciplines active in the field of South East Asian Studies and Asian Studies, and in particular anthropology, sociology, religious studies, history and political sciences. Furthermore, the book is of great interest to scholars working in the fields of modernization theory, sociological theory, cultural theory and theory of space and place.

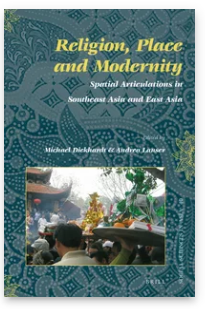

Pages: xiv, $35^{2}$ pp.

Language: English

Subjects: South East Asia, Asian Studies, Social Sciences, Asian Studies, Religion in Asia, Religious

Studies, East Asia, Asian

Studies, Religion \& Society, Social Sciences

Publisher: Brill

Series:

Social Sciences in Asia, Volume: 40

E-Book (PDF) Released online: og May 2016

ISBN: 978-9004-32023-9

List price USD $\mathrm{A}$ A $\$ 157.00$

Paperback Publication date: 19 May 2016 ISBN: 978-90- 
Michael Dickhardt is a Senior Researcher at the research network â€œDynamics of Religion in Southeast Asiaâ $€$, Georg-August-University GÃ ttingen. His current research is focused on the entanglement of religion and modernity in religious places of the Ancient Quarter of Hanoi, Vietnam.

Andrea Lauser is Professor of Anthropology in the Institute of Social and Cultural Anthropology, Georg-August-University GÃ ๆttingen. Her doctoral and post-doctoral research has focused on Southeast Asia, with a special focus on power, gender, and generation among the Mangyan of Mindoro, the Philippines, and on Filipino transnational marriage migration. From 2011 to 2015 she was the spokesperson for the research network on the dynamics of religion in Southeast Asia (www.dorisea.net). She co-edited the recent volume Engaging the Spirit World. Popular Beliefs and Practices in Modern Southeast Asia Oxford, New York (2011).

For more information see brill.com

$$
\begin{aligned}
& \text { Order information: Order online at brill.com } \\
& \text { +44 } 330333 \text { o049 | customerservices@brill.com } \\
& \text { Submission information: brill.com/authors }
\end{aligned}
$$

Titles published by Brill | Fink, Brill | mentis or Brill | Schöningh: +49(o)71 5413279216 | brill@brocom.de 